\title{
PENGARUH FAKTOR SOSIAL EKONOMI, PERILAKU PENCEGAHAN \& DUKUNGAN SOSIAL TERHADAP INFEKSI MENULAR SEKSUAL (IMS) PADA KOMUNITAS WANITA PRIA (WARIA) DI KOTA KUPANG.
}

\author{
${ }^{1}$ Imelda Getriany Thobias, ${ }^{2}$ Rafael Paun, ${ }^{3}$ Intje Picauly \\ ${ }^{1}$ Dinas Kesehatan Kabupaten Sumba Barat Daya, Nusa Tenggara Timur \\ ${ }^{2}$ Prodi Kebidanan Politeknik Kesehatan Kupang \\ ${ }^{3}$ Prodi Ilmu Kesehatan Masyarakat, FKM - Universitas Nusa Cendana
}

\begin{abstract}
ABSTRAK
Infeksi Menular Seksual (IMS) sudah menjadi masalah global sejak beberapa abad yang lalu hingga sekarang ini, dibuktikan dengan laporan terbaru World Health Organization (WHO) dan komisi gabungan PBB untuk HIV/AIDS (UNAIDS) yang diumumkan di Jenewa tahun 2009, menyatakan bahwa hampir 60 juta orang terkena penyakit HIV dan 25 juta orang meninggal akibat AIDS. IMS juga menjadi ancaman bagi masyarakat Indonesia, meski sudah memasuki era globalisasi dengan berbagai kemajuan ilmu dan teknologi, sebagian besar penduduk di tanah air masih kekurangan informasi dasar mengenai kesehatan reproduksi. Data layanan klinik Venicia pada bulan Januari sampai dengan Juni tahun 2016 jumlah waria di Kota Kupang yang terdata adalah 83 orang, jumlah ini bisa berkembang dua kali lipat karena banyak diantara mereka yang tidak terbuka dan tidak memiliki identitas resmi seperti kartu tanda penduduk (KTP). Dari 83 orang waria terdapat 31 orang yang positif menderita IMS yaitu gonore 9 kasus, clamydia 8 kasus, syphilis 4 kasus, chanroid 8 kasus, herpes 1 kasus dan melalui hasil VCT ditemukan 1 orang waria positif HIV. Tujuan penelitian Menganalisis pengaruh faktor sosial ekonomi (pendidikan, pekerjaan dan pendapatan), perilaku pencegahan (pengetahuan, sikap, niat dan tindakan) dan dukungan sosial terhadap Infeksi menular seksual (IMS) pada komunitas waria di Kota Kupang. Jenis penelitian yang digunakan adalah survei analitik dengan desain penelitian Cross sectional study. Besar sampel yang diambil adalah total populasi, yakni berjumlah 67 orang Analisa data secara deskriptif, bivariat dan multivariate. Hasil analisis bivariat dengan uji chy square menunjukan bahwa Faktor sosial ekonomi yang mempunyai pengaruh terhadap IMS pada Komunitas Waria adalah variabel Pekerjaan dan Pendapatan $(\mathrm{p}=0,031$ dan $\mathrm{p}=0,036)$. Sedangkan variabel Pendidikan tidak mempunyai pengaruh terhadap IMS $(\mathrm{p}=0,205)$, Faktor Perilaku pencegahan yang mempunyai pengaruh terhadap infeksi menular seksual pada komunitas waria adalah variabel niat $(\mathrm{p}=0,0,024)$. Sedangkan ariabel Pengetahuan, sikap dan tindakan tidak mempunyai pengaruh terhadap IMS pada komunitas waria $(p=0,625 ; p=0,834$ dan $\mathrm{p}=0,790$ ) dan Dukungan sosial tidak mempunyai pengaruh terhadap infeksi menular seksual pada komunitas waria $(\mathrm{p}=0,946)$. Analisis multivariat dengan uji regresi logistik menunjukan bahwa variabel yang paling dominan mempengaruhi IMS pada komunitas Waria yaitu Pekerjaan dan Niat.
\end{abstract}

Keywords : Transsexual, Sosial Ekonomi, Infeksi Menular Seksual 


\title{
THE INFLUENCE OF SOCIOECONOMIC FACTORS, BEHAVIOR PREVENTION \& SUPPORT SOCIAL AGAINTS SEXUALLY TRANSMITTED INFECTIONS (STIS) ON A COMMUNITY TRANSSEXUAL IN KUPANG CITY.
}

\author{
${ }^{1}$ Imelda Getriany Thobias, ${ }^{2}$ Rafael Paun, ${ }^{3}$ Intje Picauly \\ ${ }^{1}$ Southwest Sumba District Health Office, Nusa Tenggara Timur \\ ${ }^{2}$ Prodi Kebidanan Politeknik Kesehatan Kupang \\ ${ }^{3}$ Public Health program study, FKM - Universitas Nusa Cendana
}

\begin{abstract}
STIs was an issue global since several century ago until now, evidenced a recent report World Helath Organization (Organization and a joint commission The United Nation to HIV/AIDS so UNAIDS) announced in Geneva 2009, stated the nearly 60 million people affected by HIV and 25 million people died from AIDS. STIs also be a treath for the people of Indonesia, even though it has entered the era of globalization with various the advancement of science and technology, the majority of the population in the country lack basic information about reproductive health. Venicia clinik in january untuil june 2016 the number of transvestites in Kupang City recorded id 83 people, this number can develop two times for many of them not open and don't have official identification as cards id of 83 people ttransvestites there are one who positive for STIs namely gonorrhea 9 cases, clamydia 8 cases, syphilis 4 cases, chanroid 8 cases, herpes 1 case and through the rseults of VCT found one transvestites HIV positive. Research objectives analyze the influence of sosioeconomic factors (education, work and income), bahavior prevent (knowledge, attitude, intention and actions) and social support againts sexually transmitted infection (STIs) on a community transvestites in Kupang City. The kind of research used is survey analytic with the design research cross sectional stidy. Large samples to be taken is the total population were 67 people. Analysis a sort of univariate, bivariate and multivariate. The result of the analysis bivariate by test chysquare showed that sosioeconomic factors that have laverage to STIs on a community transvestites is the variable work and income $(\mathrm{p}=0,031$ and $\mathrm{p}=0,036$ ). Factors behavior prevention that have laverage to STIs on a community transvestites is the variable of intentions $(\mathrm{p}=0,0024)$. And support social have no the effect on sexually transmitted infection on a community transvestites $(\mathrm{p}=0,946)$. Multivariate analysis by test regression logistics showed that variable the most dominant influence STIs on a community transvestites is work and intention.
\end{abstract}

Keywords: Transsexual, Sosioeconomic, Sexually Transmitted Infections 


\section{PENDAHULUAN}

Infeksi menular seksual (IMS) merupakan penyakit yang penularannya melalui hubungan seksual dimana hubungan seksual ini bisa terjadi melalui genitogenital (alat kelamin dengan alat kelamin), anogenital (anus dengan alat kelamin), maupun orogenital (mulut dengan alat kelamin) (Setiawan, 2006).

IMS sudah menjadi masalah global sejak beberapa abad yang lalu hingga sekarang ini, dibuktikan dengan laporan terbaru World Health Organization (WHO) dan komisi gabungan PBB untuk HIV/AIDS (UNAIDS) yang diumumkan di Jenewa tahun 2009, menyatakan bahwa hampir 60 juta orang terkena penyakit HIV dan 25 juta orang meninggal akibat AIDS. IMS juga menjadi ancaman bagi masyarakat Indonesia, meski sudah memasuki era globalisasi dengan berbagai kemajuan ilmu dan teknologi, sebagian besar penduduk di tanah air masih kekurangan informasi dasar mengenai kesehatan reproduksi (Setiawan, 2006).

Waria adalah salah satu kaum minoritas yang mendapat diskriminasi dan stigma. Bahkan, komunitas ini sering mendapat tekanan dan intimidasi.Akibat dari hal tersebut, peluang waria untuk mengakses berbagai layanan sangat kecil. Bahkan layanan yang mendasar yaitu dalam hal mendapatkan mata pencaharian seringkali tidak bisa mereka peroleh.Waria juga merupakan kelompok risiko tinggi yang rentan terhadap Infeksi menular seksual (IMS), HIV dan AIDS. Waria memiliki jumlah pasangan seks lebih banyak dibandingkan dengan kelompok berisiko tinggi lainnya. Hal ini dikarenakan, waria lebih banyak bekerja menjajakan seks demi uang, dengan pendapatan yang sangat rendah. (Hartono, 2009).

Data statistik Ditjen Pengendalian Penyakit dan Penyehatan Lingkungan (PP dan PL) Kemenkes tahun 2014 menyatakan bahwa angka penderita IMS meningkat dari tahun ke tahun. Kasus penderita yang positif HIV sampai dengan Febuari 2014 secara kumulatif berjumlah 29.037 kasus dan yang positif AIDS adalah 5.608 kasus, proporsi kasus HIV dan AIDS tertinggi yaitu pada kelompok umur 20-49 tahun (70,4\%). Sedangkan berdasarkan cara penularan terbanyak melalui hubungan heteroseksual (52,0\%), Injection Drug Use /IDU (6,6\%), Laki-laki suka Laki-laki (LSL) (14,3\%), dan perinatal (2,7\%) (Ditjen PP\&PL Kemenkes, 2014). Data terakhir dari Komisi Penanggulangan AIDS (KPA) pada tahun 2012, jumlah Laki-Laki Suka Laki-Laki (LSL) di Indonesia sudah mencapai 800.000 orang dan di NTT mencapai 9.517 orang dan terbanyak di Kota Kupang yaitu sebanyak 1.498 orang dimana LSL lebih besar jumlahnya dibandingkan dengan wanita penyuka sesama (WPS) yang hanya 523 orang.

Angka kumulatif jumlah penderita HIV \& AIDS sampai Juni 2016 sebanyak 877 kasus dan penderita IMS sebanyak 472 kasus. Ketersediaan data terpilah berdasarkan populasi beresiko ini tidak tersedia secara khusus (Dinkes Kota Kupang,2016). Data layanan klinik Venicia pada bulan Januari sampai dengan Juni tahun 2016 jumlah waria di Kota Kupang yang terdata adalah 83 orang, jumlah ini bisa berkembang dua kali lipat karena banyak diantara mereka yang tidak terbuka dan tidak memiliki identitas resmi seperti kartu tanda penduduk (KTP). Dari 83 orang waria terdapat 31 orang yang positif menderita IMS yaitu gonore 9 kasus, clamydia 8 kasus, syphilis 4 kasus, chanroid 8 kasus, herpes 1 kasus dan melalui hasil VCT ditemukan 1 orang waria positif HIV.

Komunitas waria paling banyak berkembang di kota-kota besar karena memiliki tingkat mobilitas yang tinggi. Kota Kupang merupakan kota yang sarat dengan dunia industri dan hiburan disamping itu kehadiran waria sangat diterima baik di Kota Kupang apabila dibandingkan dengan kota-kota besar lainnya seperti Jakarta, Surabaya, Bandung, dll. Hal ini dibuktikan dengan adanya penyelenggaraan kontes waria tercantik yang diadakan setiap 
tahun di Teddys Kupang. Dengan demikian Kota Kupang dapat dijadikan sebagai barometer perkembangan waria dalam kaitannya dengan prevalensi IMS di NTT (Denimars, 2011).

\section{METODE PENELITIAN}

Jenis penelitian yang digunakan adalah survei analitik dengan desain penelitian Cross sectional study. Penelitian ini dilaksanakan pada komunitas waria yang ada di Kota Kupang. Waktu penelitian ini dilaksanakan pada bulan Januari sampai Juni 2017. Populasi dalam penelitian ini adalah seluruh waria yang ada di Kota Kupang yang berjumlah 83 orang. Besar sampel yang diambil adalah total populasi, yakni berjumlah 67 orang. Teknik pengambilan sampel menggunakan total sampling atau sampling jenuh.

Jenis analisis data yang di gunakan adalah analisis bivariat, dan multivariat. Analisis bivariat dilakukan untuk melihat pengaruh antara variabel independen dengan variabel dependen dan berapa besar pengaruh tersebut jika dihubungkan dengan uji statistic ChiSquare dan analisis multivariat dilakukan uji regresi logistik, sehingga dapat dilihat variabel mana yang paling dominan berpengaruh terhadap IMS pada komunitas Waria.

\section{HASIL DAN PEMBAHASAN}

Hasil penelitian menunjukan bahwa pada variabel IMS responden yang menderita penyakit infeksi menular seksual sebanyak 26 orang $(38,8 \%)$ dan yang tidak menderita IMS sebanyak 41 orang $(61,2 \%)$. Pada variabel Pengetahuan, sebagian responden memiliki tingkat pengetahuan baik yaitu 44 orang $(65,7 \%)$ sedangkan sebagian responden yng memiliki tingkat pengetahuan yang kurang baik yaitu 23 orang (34,3\%). Distribusi Responden berdasarkan IMS, Pengetahuan, Sikap, Niat, Tindakan, Perilaku Pencegahan dan Dukungan Sosial di Kota Kupang dapat dilihat pada tabel 1.

Tabel 1. Distribusi responden berdasarkan IMS, Pengetahuan, Sikap, Niat, Tindakan, Perilaku Pencegahan dan Dukungan Sosial di Kota Kupang.

\begin{tabular}{|c|c|c|}
\hline Variabel & Jumlah (n) & Persentase (\%) \\
\hline \multicolumn{3}{|l|}{ IMS } \\
\hline Ya & 26 & 38,8 \\
\hline Tidak & 41 & 61,2 \\
\hline \multicolumn{3}{|l|}{ Pengetahuan } \\
\hline Kurang baik & 23 & 34,3 \\
\hline Baik & 44 & 65,7 \\
\hline \multicolumn{3}{|l|}{ Sikap } \\
\hline Kurang baik & 35 & 52,2 \\
\hline Baik & 32 & 47,8 \\
\hline \multicolumn{3}{|l|}{ Niat } \\
\hline Kurang baik & 43 & 64,2 \\
\hline Baik & 24 & 35,8 \\
\hline \multicolumn{3}{|l|}{ Tindakan } \\
\hline Kurang baik & 53 & 79,1 \\
\hline Baik & 14 & 20,9 \\
\hline \multicolumn{3}{|c|}{ Perilaku Pencegahan } \\
\hline Kurang Baik & 38 & 56,7 \\
\hline Baik & 29 & 43,3 \\
\hline \multicolumn{3}{|l|}{ Dukungan Sosial } \\
\hline Kurang Baik & 39 & 58,2 \\
\hline Baik & 28 & 41,8 \\
\hline
\end{tabular}

Pada variabel sikap, sebagian besar responden memiliki sikap yang kurang baik yaitu 35 orang $(52,2 \%)$ sedangkan sebagian responden memiliki sikap yang baik yaitu 32 orang $(47,8 \%)$. Sikap yang dimaksud adalah bagaimana responden bereaksi atau menyikapi hal-hal yang berhubungan dengan IMS dan pencegahannya. Pada variabel niat, responden yang 
memiliki niat kurang baik sebanyak 43 orang $(64,2 \%)$ dan responden yang memiliki niat baik sebanyak 24 orang $(35,8 \%)$..

Pada variabel tindakan, sebagian besar responden memiliki tindakan yang kurang bauk yaitu 53 orang $(79,1 \%)$ dan sebagiannya lagi memiliki tindakan yang baik yatu 14 orang (20,9\%). Pada variabel perilaku pencegahan, sebagian besar reponden memiliki perilaku pencegahan yang kurang baik yaitu 36 orang $(56,7 \%)$ dan responden yang memiliki perilaku pencegahan yang baik sebanyak 29 orang $(43,3 \%)$. Pada variabel dukungan sosial, sebagian besar responden memiliki dukungan sosial yang kurang baik yaitu 39 orang $(58,2 \%)$ sedangkan responden yang memiliki dukungan sosial yang baik yaitu 28 orang $(41,8 \%)$.

\section{Pengaruh faktor sosial ekonomi (pendidikan, pekerjaan \& pendapatan) terhadap infeksi menular seksual pada komunitas waria.}

\section{Pengaruh Pendidikan terhadap infeksi menular seksual pada komunitas waria}

Hasil Penelitian menunjukan bahwa variabel pendidikan tidak mempunyai pengaruh yang signifikan terhadap infeksi menular seksual pada komunitas waria di kota Kupang Tahun 2017 karena memiliki nilai $p$ value $=0,205$ ( $\mathrm{p}<0,25)$. Hasil penelitian ini sejalan dengan penelitian dilakukan Hartono (2009) menyatakan bahwa tidak ada hubungan antara pendidikan dengan kejadian PMS ( $\mathrm{p}=0,067)$. Penelitian ini tidak sejalan dengan penelitian yang dilakukan oleh Tuti (2010) menyatakan bahwa ada hubungan signifikan antara pendidikan dengan kejadian PMS dengan nilai $\mathrm{p}=0,001$, aspek pendidikan berpeluang terjadi risiko terhadap PMS sebesar 3,742 kali.

Secara teori bahwa tingkat pengetahuan seseorang di pengaruhi oleh tingkat pendidikan. Tingkat pendidikan seseorang relevansinya akan mempengaruhi dalam memahami suatu informasi atau pengetahuan yang ia dapatkan. Biasanya semakin tinggi tingkat pendidikan seseorang akan lebih mudah menangkap dan memahami informasi yang didapat. Menurut peneliti tingkat pendidikan merupakan salah satu faktor penentu seseorang dalam berfikir dan bertindak. Seseorang yang memiliki pendidikan yang tinngi akan lebih mudah menangkap dan memahami informasi yang diterima. Hasil penelitian menunjukan bahwa sebagian responden yang mempunyai tingkat pendidikan SMA menderita penyakit IMS jika dibandingkan dengan responden sekolah dasar. Hal ini menunjukan bahwa pendidikan yang tinggi tidak menjamin seseorang bisa menerima informasi dan mengaplikasikan dalam kehidupan sehari-hari.

\section{Pengaruh Pekerjaan terhadap infeksi menular seksual pada komunitas waria}

Hasil penelitian menunjukan bahwa variabel ini memiliki pengaruh yang signifikan terhadap IMS pada komunitas waria di Kota Kupang tahun 2017 karena memiliki nilai $p$ value $=0,031(\mathrm{p}<0,25)$ dan nilai $\mathrm{RP}=2,06(>1)$ yang berarti variabel pekerjaan merupakan faktor risiko timbulnya kejadian penyakit IMS. Dengan demikian dapat disimpulkan bahwa ada pengaruh pekerjaan terhadap IMS pada Komunitas waria.

Hasil penelitian ini tidak sejalan dengan penelitian Hartono (2009) yang menyatakan bahwa tidak ada hubungan antara pekerjaan dengan kejadian PMS ( $\mathrm{p}=0,719)$. Meskipun pekerjaan tidak mempunyai hubungan dengan kejadian PMS namun Hartono menyebutkan bahwa pada kelompok pendidikan rendah mempunyai peluang risiko 0,63 kali lipat terjadinya PMS. Hasil analisis pada penelitian ini menunjukan bahwa ada pengaruh pekerjaan terhadap IMS, hal ini bertolak belakang dengan penelitian yang dilakukan oleh Hutagalung (2002) menyatakan bahwa tidak ada hubungan pekerjaan dengan tindakan anak jalanan terhadap risiko terkena IMS.

Pekerjaan akan menentukan status sosial ekonomi karena dari bekerja segala kebutuhan akan dapat terpenuhi. Pekerjaan tidak hanya mempunyai nilai ekonomi namun 
usaha manusia untuk mendapatkan kepuasan dan mendapatkan imbalan atau upah, berupa barang dan jasa dalam memenuhi kebutuhan hidupnya. Pekerjaan seseorang akan mempengaruhi kemampuan ekonominya, untuk itu bekerja merupakan suatu keharuan bagi setiap individu sebab dalam bekerja mengandung dua segi, kepuasan jasmani dan terpenuhinya kebutuhan hidup.

Menurut peneliti tingkat penghasilan seseorang dlilhat dari pekerjaan. Dengan bekerja sesorang dapat memenuhi kebtuhan sehari-hari. Hasil penelitian di lapanagan menunjukan bahwa sebagian besar responden yang memiliki pekerjaan lebih tinggi menderita IMS dari pada responden yang tidak memiliki pekerjaan. Responden mengaku bekerja untuk menafkahi keluarga dan sebagian penghasilan digunakan untuk membaayai pasangan mereka baik itu pasangan tetap (kandung) ataupun pasangan tidak tetap (tiri). Hal ini mencerminkan kehidupan yang bertentangan dengan norma agama dimana responden berganti-ganti pasangan dalam melakukan hubungan seksual dengan sesama jenis.

\section{Pengaruh Pendapatan terhadap infeksi menular seksual pada komunitas waria}

Hasil penelitian menunjukan bahwa variabel ini memiliki pengaruh yang signifikan terhadap IMS pada komunitas waria di Kota Kupang tahun 2017 karena memiliki nilai $p$ value $=0,036(\mathrm{p}<0,25)$ dan nilai $\mathrm{RP}=1,73(>1)$ yang berarti variabel pendapatan merupakan faktor risiko timbulnya kejadian penyakit IMS. Dengan demikian dapat disimpulkan bahwa ada pengaruh pendapatan terhadap IMS pada Komunitas waria.

Hasil Penelitian ini tidak sejalan dengan penelitian Zulkarnaen (2014) menyatakan bahwa tidak ada hubungan antara pendapatan dengan kejadian PMS di Makasar ( $\mathrm{p}=0,076$ ). Pendapatan adalah jumlah semua hasil suatu pekerjaan yang diterima oleh individu yang diwujudkan dalam bentuk uang ataupun barang. Menurut Soemardi (2007) mengemukakan bahwa pendapatan yang diterima oleh penduduk akan dipengaruhi oleh tingkat pendidikan yang ditempuh. Dengan pendidikan yang tinggi, mereka akan dapat memperoleh kesempatan yang lebih luas untuk medapatkan pekerjaan yang lebih baik disertai dengan pendapatan yang lebih besar. Sedangkan bagi penduduk yang berpendidikan rendah akan mendapatkan pekerjaan dengan pendapatan yang lebih kecil.

Menurut peneliti pendapatan seseorang sangat berpengaruh pada tingkat kesejahteraan seseorang. Tingkat pendapatan yag tinggi akan membantu individu dalam memenuhi kebutuhan material dan kebtuhan lainnya baik dalam keluarga maupun dalam hidup berorganisasi. Hasil penelitian menunjukan bahwa sebgaian besar responden yang memperolah pendapatan yang tinggi menderita penyakit IMS jika dibandingkan dengan responden yang mempunyai pendapatan yang rendah. Hal ini menggambarkan bahwa responden yang mampu dari aspek finansial lebih mudah mengakses informasi baik positip maupun negative serta dengan mudah mendapatkan orang yang akan menjadi pasangan kencan demi mendapatkan kepuasan seksualitas.

\section{Pengaruh Faktor Perilaku pencegahan ( Pengetahuan, Sikap, Niat dan Tindakan ) terhadap Infeksi Menular Seksual Pada Komunitas Waria.}

\section{Pengaruh Pengetahuan terhadap infeksi menular seksual pada komunitas waria}

Hasil penelitian menunjukan bahwa variabel ini tidak memiliki pengaruh yang signifikan terhadap IMS pada komunitas waria di Kota Kupang tahun 2017 karena memiliki nilai $p$ value $=0,625(\mathrm{p}<0,25)$ dan nilai $\mathrm{RP}=0,85(<1)$ yang berarti variabel pengetahuan adalah variabel protektif yang justru akan menguruangi kejadian penyakit IMS. Dengan demikian dapat disimpulkan bahwa tidak ada pengaruh pengetahuan terhadap IMS pada Komunitas waria. 
Hasil penelitian yang dilakukan oleh Juliastika (2012) mendukung hasil penelitian ini yaitu tidak ada hubungan pengetahuan dengan perilaku pencegahan HIV pada wanita pekerja seksual di Kota Manado $(\mathrm{p}=0,092)$. Penelitian ini juga sejalan dengan penelitian Hartono (2009) pada salah satu LSM gay di Yogyakarta menunjukkan bahwa tidak ada hubungan antara pengetahuan dengan kejadian IMS pada komunitas homoseksual ( $p=$ 0,709). Hartono menjelaskan bahwa adanya faktor lingkungan dan sosial budaya masyarakat. Walaupun seorang waria berpengetahuan baik tetapi lingkungan tempat tinggal mereka sangat mempengaruhi pembentukan perilaku seksual mereka. Seperti tinggal di lingkungan homoseksual maka seseorang dapat berpeluang terpengaruh dengan hal serupa, yakni sebagai homoseksual dengan menerapkan perilaku seks yang tidak sehat. Namun hasil penelitian ini tidak sejalan dengan hasil penelitian Suwandani (2015) menyatakan bahwa ada hubungan pengetahuan dengan kejadian IMS pada waria $(\mathrm{p}=0,007)$ dan Rahmayani (2013) yang menyatakan bahwa ada hubungan antara pengetahuan dengan pencegahan IMS pada waria di Kota Padang $(\mathrm{p}=0,040)$. Rahmayani menjelaskan bahwa adanya hubungan yang bermakna antara pengetahuan waria dengan meningkatnya kejadian IMS. Hal ini disebabkan karena pengetahuan seseorang dapat berubah dan berkembang sesuai dengan kemampuan, kebutuhan, pengalaman dan tinggi rendahnya mobilitas materi informasi tentang IMS.

Notoatmodjo (2014) mengatakan bahwa pengetahuan (knowledge) merupakan hasil tahu dan ini terjadi setelah orang melakukan penginderaan terhadap objek tertentu. Pengetahuan merupakan domain yang sangat penting untuk terbentuknya tindakan atau perilaku sesorang. Pengetahuan dapat mempengaruhi kesehatan seseorang bila didasari oleh kesadaran dan sikap positif sesuai dengan tingkatan pengetahuan yang dibagi menjadi 6 tingkat, dimana pengetahuan mulai berpengaruh terhadap kesehatan seseorang yaitu ketika berada dalam tahapan application yang berarti seseorang tersebut dapat mempergunakan pengetahuannya untuk diaplikasikan dalam kehidupan sehari-hari (Notoadmojo,2011).

Penelitian ini berbeda dengan penelitian lainnya karena menurut peneliti tidak ada kesadaran pada diri responden untuk mengaplikasikan pengetahuan yang telah mereka peroleh sehingga meski tingkat pengetahuan mereka baik namun tidak berpengaruh terhadap kesehatan mereka. Menurut peneliti pengetahuan akan IMS sangat diperlukan di berbagai kalangan terutama di kalangan waria yang rentan dengan perilaku seks bebas. Hasil penelitian pada kelompok waria menujukan bahwa sebagain besar responden dapat menjawab dengan benar tentang cara penularan dan pencegahan IMS dan masih sedikit orang yang mempunyai pemahaman yang salah tentang IMS. Pengetahuan yang kurang atau persepsi yang salah akan informasi yang diterima akan berpengaruh negative terhadap perilaku seseorang dalam bertindak. Responden sebagian besar berpengetahuan baik menderita IMS, hal ini dapat disebabkan oleh faktor lain salah satunya adalah lingkungan dimana waria bertempat tinggal dalam satu komunitas yang hidup sehari-harinya selalu bersama-sama dengan gaya hidup yang bertentangan dengan nilai dan norma yang berlaku di masyarakat.

\section{Pengaruh Sikap terhadap infeksi menular seksual pada komunitas waria}

Hasil penelitian menunjukan bahwa variabel ini tidak memiliki pengaruh yang signifikan terhadap IMS pada komunitas waria di Kota Kupang tahun 2017 karena memiliki nilai $p$ value $=0,834(\mathrm{p}<0,25)$ dan nilai $\mathrm{RP}=1,00(=1)$ yang berarti variabel sikap adalah variabel yang belum dapat dipstikan sebagai faktor risiko atau faktor protektif. Dengan demikian dapat disimpulkan bahwa tidak ada pengaruh pengetahuan terhadap IMS pada Komunitas waria. 
Hasil penelitian ini bertolak belakang dengan penelitian yang dilakukan oleh dan Budiarti (2015). Buadiarti menyatakan bahwa ada hubungan sikap dengan perilaku pencegahan IMS di Kota Surakarta $(\mathrm{p}=0,001)$. Budiarti menjelaskan bahwa seseorang yang memiliki sikap baik terhadap pencegahan IMS memiliki kecenderungan untuk berperilaku yang baik pula. Penelitian yang dilakukan Suwandani ((2015) menyatakan bahwa ada hubungan sikap dengan IMS pada waria $(\mathrm{p}=0,001)$. Suwandani menjelaskan bahwa sikap kurang yang ditunjukan waria disebabkan oleh ketidakmampuan waria dalam mengambil keputusan dalam memakai kondomkarena faktor pasangan.

Sikap adalah respon tertutup seseorang terhadap stimulus atau objek tertentu yang sudah melibatkan faktor pendapat dan emosi yang bersangkutan, misalnya senang, tidak senang, setuju, tidak setuju, baik, tidak baik, dan sebagainya (Notoatmodjo, 2014). sikap merupakan reaksi atau respon yang masih tertutup dari seseorang terhadap suatu stimulasi atau objek. Manifestasi sikap tidak dapat dilihat secara langsung tetapi hanya bisa ditafsirkan terlebih dahulu dari perilaku yang tertutup. Sikap secara nyata menunjukan konotasi adanya kesesuaian reaksi terhadap stimulus tertentu dalam kehidupan sehari-hari.

Menurut peneliti sikap merupakan tindakan nyata dari perilaku seseorang baik hal yang baik maupun hal yang tidka baik. Hasil penelitian menunjukan bahwa sebagian responden memiliki sikap yang baik dimana responden selalu memeriksakan kesehatan untuk mengetahui kesehatannya, selalu mengikuti perintah dokter yang merawatnya, dan mau menjauhi semua resiko yang menyebabkan penyakit kelamin serta bersedia memberikan informasi yang baik kepada pasangannya. Namun masih ada sebagian responden yang memiliki sikap kurang baik antara lain mau melakukan hubungan seks dengan pasangan tetap maupun pasangan tiri. Hal ini menggambarkan bahwa masih ada sebagian reponden yang belum menyadari bahwa penyakit IMS akan berbahaya untuk kesehatannya.

\section{Pengaruh Niat terhadap infeksi menular seksual pada komunitas waria}

Hasil penelitian menunjukan bahwa variabel ini memiliki pengaruh yang signifikan terhadap IMS pada komunitas waria di Kota Kupang tahun 2017 karena memiliki nilai $p$ value $=0,024(\mathrm{p}<0,25)$ dan nilai $\mathrm{RP}=1,84(>1)$ yang berarti variabel Niat Merupakan faktor risiko timbulnya kejadian penyakit IMS. Dengan demikian dapat disimpulkan bahwa ada pengaruh pengetahuan terhadap IMS pada Komunitas waria

Hasil Penelitian ini tidak sejalan dengan hasil penelitian Eda (2012) menyatakan bahwa Sebagian besar responden $(55,6 \%)$ mempunyai niat menggunakan kondom dalam melakukan hubungan seksual. Perilaku menurut Theory of Reasoned Action (TRA) dipengaruhi oleh niat, sedangkan niat dipengaruhi oleh sikap dan norma subyektif. Sikap sendiri dipengaruhi oleh keyakinan akan hasil dari tindakan yang telah lalu. Norma subyektif dipengaruhi oleh keyakinan akan pendapat orang lain serta motivasi untuk menaati pendapat tersebut.

Jogiyanto (2007) berpendapat bahwa Intensi atau niat merupakan fungsi dari dua determinan dasar, yaitu sikap individu terhadap perilaku (merupakan aspek personal) dan persepsi individu terhadap tekanan sosial untuk melakukan atau untuk tidak melakukan perilaku yang disebut dengan norma subyektif. Secara lebih sederhana, teori ini mengatakan bahwa seseorang akan melakukan suatu perbuatan apabila ia memandang perbuatan itu positif dan bila ia percaya bahwa orang lain ingin agar ia melakukannya.

Hasil penelitian menyatakan bahwa waria memiliki niat kurang $(64,2 \%)$, hal ini kemungkinan disebabkan oleh kepedulian kesehatan diri pada waria yang kurang karena faktor lebih menuruti emosi yaitu ingin mendapatkan kepuasan yang lebih bagi pasangan dan materi yang lebih tanpa memikirkan risiko . 
Hasil penelitian di lapangan menunjukan bahwa sebagain kecil responden mempunyai niat yang baik yang mana responden mengaku mau berhubungan seks tetapi menggunakan kondom dan responden yakin bahwa jika memakai kondom dalam berhubungan seks akan terhindar dari penyakit kelamin. Namun sebagian besar responden mempunyai niat kurang baik antara lain berhubungan seks dengan pasangan tetap namun tidak menggunakan kondom, jika sakit tidak bersedia untuk berkonsultasi dengan dokter dan tidak mencari informasi untuk menolong dirinya keluar dari permasalahan yang dapat berbahaya untuk kesehatannya. Waria memiliki niat yang kurang terhadap pencegahan IMS karena dia berasumsi bahwa dengan memakai kondom akan mengurangi sensasi dan pasangannya menjadi kurang puas.

\section{Pengaruh Tindakan terhadap infeksi menular seksual pada komunitas waria}

Hasil penelitian menunjukan bahwa variabel ini tidak memiliki pengaruh yang signifikan terhadap IMS pada komunitas waria di Kota Kupang tahun 2017 karena memiliki nilai $p$ value $=0,790(\mathrm{p}<0,25)$ dan nilai $\mathrm{RP}=1,11(=1)$ yang berarti variabel tindakan adalah variabel yang belum dapat dipstikan sebagai faktor risiko atau faktor protektif. Dengan demikian dapat disimpulkan bahwa tidak ada pengaruh tindakan terhadap IMS pada Komunitas waria.

Hasil penelitian ini tidak sejalan dengan penelitian yang dilakukan oleh Rachmayani (2013). Rachmayani menyatakan bahwa sebagian besar waria di Kota Padang memiliki tindakan yang baik $(65 \%)$ terhadap pencegahan HIV AIDS. Suatu sikap belum otomatis terwujud dalam suatu tindakan (overt behavior). Untuk mewujudkan sikap menjadi suatu perbuatan yang nyata diperlukan faktor pendukung atau suatu kondisi yang memungkinkan. Rogers (1974) mengungkapkan bahwa sebelum orang mengadopsi perilaku baru didalam diri orang tersebut terjadi proses berurutan yakni : (1) Kesadaran (Awareness) Dimana orang tersebut menyadari dalam arti mengetahui terlebih dahulu terhadap stimulus (objek). (2) Tertarik (Interest) Dimana orang mulai tertarik pada stimulus, (3) Evaluasi (Evaluation) Menimbang-nimbang terhadap baik an tidaknya stimulus tersebut bagi dirinya. Hal ini berarti sikap responden sudah lebih baik lagi. (4) Mencoba (Trial) Dimana orang telah mulai mencoba perilaku baru. (5) Menerima (Adoption) Dimana subyek telah berperilaku baru sesuai dengan pengetahuan, kesadaran dan sikapnya terhadap stimulus.

Penelitian dilapangan menunjukan bahwa sebagian kecil responden mempunyai tindakan yang baik dimana responden menyediakan kondom sebelum melakukan hubungan seksual dengan pasangannya, jika kondom kondom tidak tersedia responden berusaha untuk membeli atau kalau tidak ada kondom responden menahan diri atau menolak untuk melakukan hubungan seksual. Namun sebagian besar responden mempunyai tindakan yang kurang baik dimana responden mau melakukan hubungan seksual dengan tidak menggunakan kondom dan tidak berupaya untuk melakukan tindakan yang baik. Hal ini sangat berpengaruh pada komunitas waria dan pada masyarakat pada umumnya karena responden dapat menyebarkan penularan penyakit kepada siapa saja yang berhubungan seks dengan responden.

\section{Pengaruh Perilaku Pencegahan terhadap infeksi menular seksual pada komunitas waria}

Perilaku Pencegahan yang dimaksud disini adalah nilai mix dari pengetahuan, sikap, niat dan tindakan. Hasil penelitian menunjukan bahwa variabel ini tidak memiliki pengaruh yang signifikan terhadap IMS pada komunitas waria di Kota Kupang tahun 2017 karena memiliki nilai $p$ value $=0,254(\mathrm{p}<0,25)$ dan nilai $\mathrm{RP}=1,41(>1)$ yang berarti variabel perilaku pencegahan Merupakan faktor risiko timbulnya kejadian penyakit IMS. Dengan demikian dapat disimpulkan bahwa tidak ada pengaruh perilaku pencegahan terhadap IMS pada Komunitas waria 
Perilaku manusia merupakan hasil daripada segala macam pengalaman serta interaksi manusia dengan lingkungannya yang terwujud dalam bentuk pengetahuan, sikap dan tindakan. Dengan kata lain perilaku merupakan respon/reaksi seorang individu terhadap stimulus yang berasal dari luar maupun dari dalam dirinya. (Sarwono,2004).

Hasil penelitian di lapangan menunjukan bahwa sebagian kecil responden mempunyai perilaku pencegahan yang baik. Responden menyadari bahwa IMS merupakan penyakit menular seksual yang dapat ditularkan melalui hubungan seksual. Responden mengaku untuk mencegah terjangkitnya penyakit IMS harus merubah semua perilaku yang bertentangan dengan nilai dan norma yakni tidak melakukan hubungan seksual dengan siapa saja untuk menghindari tertularnya penyakit kelamin. Responden bersedia memberikan informasi tentang IMS kepada teman sebaya dan komunitas sebagai salah satu upaya untuk menyadarkan teman-temannya dalam merubah gaya hidup yang kurang baik menjadi baik dengan melakukan kegiatan-kegiatan di masyarakat serta mendekatkan diri dengan Tuhan dalam membangun kehidupan di masa yang akan datang yang dapat bermanfaat bagi diri, keluarga dan masyarakat. Namun pada penelitian ini sebagian besar responden memiliki perilaku pencegahan yang kurang. Hal ini disebabkan karena hampir semua responden walaupun memiliki pengetahuan yang baik namun sikap, niat dan tindakan masih kurang.

\section{Pengaruh Dukungan Sosial terhadap Infeksi Menular Seksual pada komunitas waria}

Hasil penelitian menunjukan bahwa variabel ini tidak memiliki pengaruh yang signifikan terhadap IMS pada komunitas waria di Kota Kupang tahun 2017 karena memiliki nilai $p$ value $=0,946(\mathrm{p}<0,25)$ dan nilai $\mathrm{RP}=0,97(<1)$ yang berarti variabel dukungan sosial adalah variabel protektif yang justru akan mengurangi kejadian penyakit IMS. Dengan demikian dapat disimpulkan bahwa tidak ada pengaruh dukungan sosial terhadap IMS pada Komunitas waria.

Hasil penelitian ini tidak sejalan dengan penelitian yang dilakukan oleh Hardiyatmi (2016) menyatakan bahwa ada hubungan dukungan keluarga dengan kepatuhan program pengobatan pasien VCT di RSUD dr. Soediran Mangun Soemarso Wonogiri (p-0,009). Hal serupa juga dikemukakan oleh Andra (2006) bahwa ada hubungan dukungan sosial keluarga terhadap respon sosial emosional pasien HIV ( $\mathrm{p}=0,002)$.

Dukungan sosial ( social support) di defenisikan sebagai informasi verbal atau nonverbal, saran, bantuan yang nyata atau tingkah laku yang diberikan oleh orang-orang yang akrab dengan subjek didalam lingkungan socialnya atau yang berupa kehadiran dan hal yang dapat memberikan keuntungan emosional atau berpengaruh pada tingkah laku. Pendapat senada juga mengatakan bahwa dukungan sosial adalah keberadaan, kesediaan, kepeduliaan dari orang sekitar. Pandangan yang sama juga mendefinisikan dukungan sosial sebagai adanya kenyamanan, perhatian, penghargaan atau menolong orang dengan sikap menerima kondisinya, dukungan sosial tersebut diperoleh dari individu maupun kelompok.

Dukungan sosial sebagai sumber emosional, informasional atau pendampingan yang diberikan oleh orang-orang disekitar individu untuk menghadapi setiap permasalahan dan krisis yang terjadi sehari-hari di dalam kehidupan. Dukungan sosial sebagai dukungan atau bantuan yang berasal dari orang lain seperti teman, tetangga, teman kerja dan orang-orang lainnya. Dukungan sosial mengacu pada memberikan kenyamanan pada oranglain, merawatnya atau menghargainya. Selain itu, dukungan sosial adalah adanya transaksi interpersonal yang ditunjukkan dengan memberikan bantuan pada individu lain, dimana bantuan itu umumnya diperoleh dari orang yang berarti bagi individu yang bersangkutan. Dukungan sosial dapat berupa pemberian informasi, bantuan tingkah laku, ataupun materi yang didapat dari hubungan sosial akrab yang dapat membuat individu merasa diperhatikan, bernilai, dan dicintai ( A. Heaney Chaterine, Barbara A. Israel, 2008 dalam Paun, Rafael $2016)$. 
Hasil penelitian di lapangan menunjukan bahwa sebagian besar responden mendapat dukungan yang social yang baik dari keluarga. Dukungan keluarga sangat membantu waria dalam menjalani hidupnya sehari-hari. Keluarga memberikan perhatian jika sakit dan keluarga selalu menghargai dan memberikan support kepada waria. Namun masih ada sebagian waria yang mempunyai dukungan social yang kurang antara lain tidak ada dukungan social dari keluarga. Waria mengaku keluarga mereka malu dengan keadaan mereka sebagai waria, penyakit yang diderita dan tidak peduli dengan kesehatan waria bahkan ada yang memutuskan hubungan kekeluargaan dengan waria. Keluarga tidak memberikan fasilitas apapun kepada waria termasuk informasi tentang IMS serta tidak menghargai pendapat waria. waria yang kurang mendapatkan dukungan sosial pada umumnya pasrah bahkan tidak peduli dengan hubungan mereka dengan keluarga dan kondisi yang dialami. Waria kehilangan orang-orang terdekat yang dapat mempengaruhi emosional waria dalam bertindak dan mengambil keputusan.

\section{PENUTUP}

Simpulan.

Dari hasil penelitian ini dapat disimpulkan bahwa:

1) Faktor sosial ekonomi yang mempunyai pengaruh terhadap IMS pada Komunitas Waria adalah variabel Pekerjaan dan Pendapatan $(\mathrm{p}=0,031$ dan $\mathrm{p}=0,036)$. Sedangkan variabel Pendidikan tidak mempunyai pengaruh terhadap IMS $(\mathrm{p}=0,205)$

2) Faktor Perilaku pencegahan yang mempunyai pengaruh terhadap infeksi menular seksual pada komunitas waria adalah variabel niat $(\mathrm{p}=0,0,024)$. Sedangkan ariabel Pengetahuan, sikap dan tindakan tidak mempunyai pengaruh terhadap IMS pada komunitas waria ( $\mathrm{p}=0,625 ; \mathrm{p}=0,834$ dan $\mathrm{p}=0,790)$

3) Dukungan sosial tidak mempunyai pengaruh terhadap infeksi menular seksual pada komunitas waria $(\mathrm{p}=0,946)$

\section{DAFTAR PUSTAKA}

Denimars,2011. Epidemiologi Infeksi Menular Seksual. Kupang

Ditjen PP dan PL Kemenkes RI. 2014. Statistik Kasus HIV/AIDS di Indonesia. Jakarta.

Hartono, 2009. Dikutip dari Skripsi Faktor risiko kejadian IMS pada Komunitas Gay di Kota Yogjakarta 2009

Hutapea, 2003. HIV/AIDS dan Infeksi menular seksual. Jakarta: Cipta Pustaka

Juniawan Kadek, 2010. Mari katong berbagi informasi. Kupang

Karjono dan Kristiawan, 2009. Intisari Epidemiologi. Yogyakarta : Mitra Cendika

Laiskodat, 2009. Infeksi menular seksual. Kupang

Laporan STBP, 2012. Surveilans Terpadu Biologis Perilaku Pada Kelompok Berisiko Tinggi $d i$ Indonesia. Diunduh di https://www. Slideshare.net/mobile/laporan-stbp-2012.

Murti Bhisma, 2003. Prinsip dan Metode Riset Epidemiologi. Yogyakarta: GMU

Effendi, Mukhlison. 2008. Ilmu Pendidikan. Jogjakarta: Nadi Ofset.

Nadia, 2005 dikutip dari http://www.portalmadiun.web.id/profil/pengalaman-hidup-rellysalah-seorang-waria-dari-kota-madiun.html

Notoadmojo Soekidjo, 2005. Pendidikan Kesehatan Dan Perilaku . Jakarta: Rineka Cipta

Purwarini, Adisasmita, Muhaimin. 2010. Hubungan Pencarian Pengobatan IMS dengan Penggunaan Kondom pada PSK Waria di Beberapa Kota di Pulau Jawa. http://library.unej.ac.id/client/search/asset/765;jsessionid. Vol 11. Diakses tanggal 11 November 2016. 
Rahmayani, Hanif, Sastri. 2013. Hubungan Pengetahuan dan Sikap terhadap tindakan pencegahan penularan HIV/AIDS pada Waria di Kota Padang. Jurnal Kesehatan Andalas. http://jurnal.fk.unand.ac.id. Diakses tanggal 23 September 2016.

Riduwan. 2009. Dasar-Dasar Statistika. Bandung: Alfabeta.

Riyanto Agus, 2011. Penerapan Analisis Multivariat Dalam Penelitian Kesehatan. Yogyakarta. PT Nuha Medika

Santjaka, Aris. 2011. Statistik Untuk Penelitian Kesehatan. Yogyakarta: Nuha Medika

Sarwono. 2004. Sosiologi Kesehatan. Jakarta. Rineka Cipta

Sudarma, Momon. 2008. Sosiologi Kesehatan. Jakarta: Salemba Medika

Sutrisna, Bambang. 2010. Pengantar Metode Epidemiologi. Jakarta: Dian Rakyat

Yash, 2003. Dikutip dari http://www.satudunia.net/cZontent/stigma-dan-diskriminasi-padawaria 